\title{
Paradoks Demokratisasi dan Liberalisasi Pasar terhadap Gerakan Anti-Korupsi di Negara Berkembang
}

\author{
Ahmad Khoirul Umam \\ School of Political Science \& International Studies, The University of Queensland
}

\begin{abstract}
The package of neoliberal reforms involving three main components namely democratization, market liberalization, and the creation of good governance, has often adopted by a number of developing countries in order to overcome their prolonged political and economic crises. The policies which are often promoted by international donor agencies have been expected to streamline the transformation processes in the developing countries to establish a more powerful, well established and stablecountries in economics and politics. However, experiences in developing countries actually showed the opposite trends, where the concept of market structure strengthening and the reduction of state authority in the public sector have often resulted in the widening loopholes and opportunities for more systematic and structuredcorruption practices.In addition, the democratization agenda has also often facilitated the old groups of interests to get back to control of the reformed political system leading to the symptoms of neo-patrimonialism in the process of democratic transition. The impact of these symptoms is the anti-corruption agenda inclines to become more vulnerable to manipulation, intervention, and political pressures. To eliminate such trends, it needs the presence of strong leadership factor backed up by an established surveillance system in order to encourage the 'rule of law' as the supreme commander in the transformation and democratic transitional processes which are usually haunted by various turbulences. This article completely uses a literature approach by analysing secondary datafrom booksandjournals in order tolook atthe dynamicsand theoreticaldebateson prosand consof the implementationof neo-liberalpoliciesfor developing countries' anti-corruption agenda.
\end{abstract}

Keywords: anti-corruption, democratization, market liberalization, strong leadership.

\begin{abstract}
Abstrak
Paket kebijakan reformasi neo-liberal yang melibatkan tiga komponen utama, yakni agenda demokratisasi, liberalisasi pasar, serta penciptaan good governance, acapkali diadopsi oleh sejumlah negara berkembang sebagai sarana untuk mengatasi krisis politik dan ekonomi yang berkepanjangan. Paket kebijakan yang seringkali dipromosikan oleh lembaga-lembaga donor internasional itu diharapkan dapat membantu lancarnya proses transformasi kehidupan politik dan ekonomi negara-negara berkembang agar menjadi lebih kuat, mapan, dan stabil. Kendati demikian, pengalaman di negaranegara berkembang justru menunjukkan kecenderungan yang sebaliknya. Konsep penguatan struktur pasar dan pengurangan otoritas negara di sektor publik justru seringkali berakibat pada semakin melebarnya celah aturan dan kesempatan bagi perilaku korupsi yang kian sistematis dan terstruktur. Selain itu, agenda demokratisasi yang digulirkan juga seringkali memfasilitasi kelompok-kelompok lama untuk kembali menguasai sistem politik hingga memunculkan gejala neo-patrimonialisme dalam proses transisi demokrasi. Imbas gejala tersebut terhadap agenda pemberantasan korupsi adalah berubahnya dari wilayah hukum sebagai zona politis yang menjadi sangat rentan terhadap manipulasi, intervensi, dan tekanan kekuasaan.Untuk mengeliminasi kecenderungan itu, dibutuhkan hadirnya faktor kepemimpinan yang kuatdan dïmbangi oleh sistem pengawasan yang mapan, guna mendorong 'rule of law' sebagai panglima tertinggi dalam proses transformasi dan transisi demokrasi yang cenderung penuh turbulensi.Penulisan artikel ini sepenuhnya menggunakan tinjauan pustaka melalui telaah datadata sekunder di berbagai buku dan jurnal, untuk melihat dinamika perdebatan teori terkait pro dan kontra implementasi kebijakan neo-liberal dalam agenda pemberantasan korupsi di negara-negara berkembang.
\end{abstract}

Kata kunci: anti korupsi, demokratisasi, liberalisasi pasar, kepemimpinan yang kuat 


\section{Reformasi Neo-Liberal dan Efektivitas Pemberantasan Korupsi: Mitos atau Realita?}

Reformasi neo-liberal merupakan instrumen kebijakan politik dan ekonomi yang selama ini dianggap sebagai senjata ampuh untuk memberantas korupsi di sejumlah negara berkembang. Sebagaimana dipahami secara internasional seperti yang termaktub dalam United Nations Convention Againts Corruption (UNCAC) bahwa korupsi merupakan kejahatan internasional yang luar biasa (extra-ordinary crimes) dan dianggap mampu mengancam keamanan global. Di sejumlah negara berkembang, praktek korupsi yang sistematis dan terstruktur yang telah berkolaborasi dengan sistem politik yang otoritarian, kolusi dan nepotis, sering kali menjadi penyebab utama terjadinya krisis politik dan ekonomi yang berkepanjangan. Karena itu, promosi paket kebijakan yang belakangan diadopsi oleh banyak sekali negara-negara miskin dan berkembang di Asia, Afrika, dan Amerika Latin memberikan pengaruh yang sangat besar terhadap kualitas tata kelola pemerintahan di negara-negara tersebut. Kendati demikian, harapan ideal akan hadirnya good governance sebagai hasil dari pelaksanaan demokratisasi dan liberalisasi pasar guna mewujudkan sistem politik dan ekonomi yang mapan dan stabil, justru berujung pada realitas dan pengalaman yang bersifat paradoks.

Pada 1989 misalnya, sebuah kebijakan besar yang disponsori oleh World Bank, International Monetary Fund (IMF), dan Departemen Keuangan Amerika Serikat telah merumuskan sepuluh resep kebijakan ekonomi yang diperuntukkan bagi penanganan krisis ekonomi yang disebabkan oleh rendahnya kualitas tata kelola pemerintahan di sejumlah negara miskin dan berkembang. Sepuluh jurus ekonomi itu kemudian dikenal sebagai Konsensus Washington Concensus).Terminologi Washington Concencus sendiri pada mulanya diciptakan oleh John Williamson (1989) untuk mengidentifikasi paket kebijakan ekonomi yang ditujukan untuk mengatasi krisis ekonomi yang diderita oleh negara-negara berkembang. Sepuluh paket kebijakan itu antara lain; disiplin fiskal, pengalihan pengeluaran publik dari subsidi-subsidi yang terkait dengan penyediaan layanan dasar yang menunjang pertumbuhan ekonomi dan juga layanan-layanan yang berkontribusi pada kelompok miskin seperti pendidikan dasar, perawatan kesehatan, dan investasi infrastruktur. Selain itu juga reformasi perpajakan, penetapan suku bunga perbankan, nilai tukar yang kompetitif, liberalisasi perdagangan dan keleluasaan investasi asing untuk masuk dalam pasar lokal, privatisasi, deregulasi, dan kepastian hukum bagi hak-hak properti (World Bank, 2000; Kitthananan, 2008; Stigllitz, 2002: 74).

Paket kebijakan ini diramu sedemikian rupa berlandaskan prinsip dan cara pandang neoliberal yang telah terbukti mampu mempengaruhi proses transformasi kehidupan politik dan ekonomi negaranegara di berbagai belahan dunia (Robinson, 2005: 18). Konsep neoliberal ini juga telah diinternalisasikan oleh IMF, World Bank, dan World Trade Organization (WTO) di sejumlah negara-negara berkembang. Wacana pembangunan di era post-kolonial ini telah didominasi oleh ide-ide neoliberal yang dipromosikan oleh negara-negara maju untuk meningkatkan perkembangan ekonomi serta mengatasi masalah kemiskinan yang telah akut dan berkepanjangan. Sebagai bagian dari konsep ini, mekanisme pasar bebas dipercaya mampu menciptakan lompatan-lompatan besar dalam upaya peningkatan produksi dan distribusi komoditas barang diyakini sejumlah pihak mampu menurunkan angka kemiskinan secara serentak(World Bank, 2000).

Para ilmuwan neoliberal juga telah merespon krisis ekonomi di sejumlah negaranegara miskin dan berkembang ini dengan mengusulkan reformasi struktural berdasarkan manajemen ekonomi dan prinsip tata kelola pemerintahan, seperti privatisasi, penurunan kekuasaan negara, 
desentralisasi administratif, deregulasi, dan juga pembukaan gerbang pasar domestik untuk memberikan jalan leluasa bagi masuknya arus pasar global dan investasi asing (Colongan, 2003; Hofmann dan Kaiser, 2002; USAID, 2006).

Agenda reformasi neoliberal juga melibatkan tiga komponen utama, yakni liberalisasi ekonomi, penciptaan tata kelola pemerintahan yang baik terutama dalam sektor manajemen kebijakan publik, serta agenda demokratisasi untuk meningkatkan partisipasi rakyat di semua tingkatan. Logikanya, penggunaan mekanisme pasar yang diimbangi dengan pengurangan otoritas negara dalam bidang pelayanan sektor publik, diyakini dapat menjadi instrumen yang efektif memangkas dan meminimalisasi celah-celah aturan yang dapat membuka peluang bagi maraknya praktek korupsi. Selanjutnya, konsep tata kelola pemerintahan (good governance) yang melibatkan sistem desentralisasi otoritas pemerintahan, dari pusat ke daerah, juga dinilai mampu menciptakan sistem politik yang mendukung penguatan prinsip transparansi dan akuntabilitas publik. Semua strategi itu dirasa dapat mengurangi praktek-praktek korupsi dalam pelaksanaan kinerja pemerintahan. Kendati demikian, pola kompetisi yang tercipta dalam proses demokrasi, baik di tingkat lokal maupun nasional, juga tetap membutuhkan mekanisme kontrol guna menghindari praktek korupsi (Putzel, 1997; Ostorm, 1991; Oyugi, 2000).

Sebagai contoh, di negara-negara Afrika yang hidupnya sangat bergantung pada bantuan luar negeri dari negara donor dan organisasi internasional, sebagaimana yang diutarakan oleh Lowson (Lowson, 2009), reformasi neoliberal yang disponsori oleh lembaga-lembaga donor internasional telah mengampanyekan setidaknya dua model pendekatan, yakni pendekatan stuktural dan pendekatan normatif. Dalam pendekatan struktural, reformasi sangat dipengaruhi oleh definisi korupsi yang didasarkan pada logika pasar, di mana korupsi lebih cenderung dipahami sebagai konsep "rent-seeking" dan definisi mendasar tentang korupsi sebagaimana yang diformulasikan oleh Robert Klitgaard (1988) bahwa korupsi dipahami sebagai monopoli plus diskresi minus akuntabilitas $(\mathrm{C}=\mathrm{M}+\mathrm{D}$ A). Berdasarkan definisi korupsi tersebut di atas, itu berarti bahwa untuk memangkas korupsi, monopoli kekuasaan harus dihilangkan dan metode kompetisi yang sehat harus diciptakan untuk mengakses kekuasaan. Diskresi juga harus dibatasi, di mana hukum dan aturan harus diperjelas dan terhindar dari pemaknaan yang ambigu. Selanjutnya akuntabilitas atau pertanggungjawaban publik harus ditingkatkan melalui penciptaan indikatorindikator kinerja serta menerima saran dan masukan dari seluruh elemen masyarakat dan pemerintahan itu sendiri. Untuk mengurangi diskresi, dibutuhkan kebijakankebijakan privatisasi dan deregulasi. Sementara kompetisi politik dan ekonomi dipercaya dapat mengeliminasi sistem monopoli, caranya adalah dengan meningkatkan akuntabilitas politik melalui proses demokratisasi dan juga dengan mempromosikan akuntabilitas administratif dengan cara mengoptimalkan sistem birokrasi.

Di sisi lain, pendekatan normatif lebih menitikberatkan pada pentingnya kesadaran publik pada efek negatif dari praktek korupsi. Kesadaran itu tidak hanya dibutuhkan untuk menguatkan standar moral dan etika di tengah-tengah masyarakat guna meningkatkan antipati publik terhadap perilaku korupsi, tetapi juga untuk meningkatkan partisipasi publik dalam proses pengawasan di setiap proses pengambilan kebijakan, supaya norma antikorupsi dan aturan-aturan hukum tentang pencegahan dan pemberantasan korupsi menjadi lebih efektif dan efisien (Lowson, 2009; McCoy dan Heckel 2001; Villlon, 2007).

Hal lain yang harus dilakukan untuk mengefektifkan agenda pemberantasan korupsi adalah usaha memahami sebabsebab terjadinya korupsi. Dengan mengidentifikasi sebab-sebab terjadinya korupsi, maka agen anti-korupsi akan dapat merumuskan model-model strategi 
pemberantasan korupsi yang sesuai dengan realitas di sekitarnya (Williams, 1987: 19; Scott, 1972:3-4; Philp, 1997:23-25; Theobald, 1990: 12; Williams, 1999:504; World Bank, 2002: 12). Bank Dunia (World Bank,2002) misalnya, menyatakan bahwa 'the definition and causes of corruption are always contextual, rooted in a country's policies, bureaucratic traditions, political development, culture, and social history. Apa yang dianggap sebagai perilaku koruptif dan tidak etis dalam suatu budaya masyarakat yang satu, bisa juga dipandang sebagai perilaku atau transaksi rutin yang normal dan wajar dalam konteks budaya masyarakat yang lain. Di sejumlah negaranegara Asia misalnya, prinsip resiprositas yang tertuang dalam kebiasaan pemberian hadiah, yang biasanya dikategorikan sebagai suap dan perilaku korup dalam budaya Barat misalnya, justru telah memainkan peranan penting dalam hubungan antara para penguasa politik dan masyarakat sebagai simbol penghormatan dan ucapan terima kasih (Rose-Ackerman, 1999). Itulah mengapa beberapa teori-teori budaya dan peradaban sebagaimana yang dikembangkan oleh Fukuyama (Fukuyama,1998), Huntington (Huntington,1993), dan Lipset dan Lez (Lipset \& Lez,2000) mengidentifikasi beberapa negara-negara Asia, khususnya yang berada di bawah pengaruh kebudayaan Islam dan Konfusianisme, dinilai tidak cocok dengan demokrasi dan cenderung menjadi area subur dan kondusif untuk menyemai korupsi.

Upaya pemahaman kontekstual semacam itu penting untuk dilakukan, sekaligus untuk memberikan klarifikasiklarifikasi terhadap tudingan yang barangkali tidak relevan. Upaya ini juga penting dilakukan mengingat sejumlah kasus di mana agen-agen neoliberal sering kali dipandang lemah dalam memahami konsep kepentingan publik (public interest) ketika memformulasikan pemahaman yang tepat tentang korupsi.

Secara general, Bardhan (Bardhan, 1997) dan Robison (1998) misalnya, menggarisbawahi bahwa korupsi merupakan perilaku yang tidak legitimate dan merusak sektor publik, yang diwujudkan melalui pengkhianatan langsung terhadap kepercayaan publik untuk memperkaya diri sendiri (individual enrichment). Rogow dan Lasswell (Rogow \& Lasswell,1963: 132) serta Friedrich (Friedrich,1989) juga memiliki pemahaman serupa tentang korupsi, di mana lebih ditekankan pada perilaku yang melanggar kepentingan umum. Definisi korupsi yang menitikberatkan pada aspek kerugian di sektor kepentingan publik itu kemudian ditentang oleh Theobald (Theobald,1990: 5) dan Scott (Scott,1972: 3). Keduanya berpendapat bahwa terminologi yang objektif dari istilah kepentingan publik itu cenderung potensial untuk dipolitisasi hingga melenceng dari makna yang sebenarnya. Kritik lain juga diarahkan pada model pendefinisian korupsi yang menggunakan pendekatan opini publik, sebagaimana dipopulerkan oleh Gibbons (Gibbons,1989: 169). Gibbons berpendapat, definisi korupsi lebih ditentukan oleh asumsi dan pemikiran publik terhadap sebuah tindakan. Dalam konteks ini, entitas publik itu sendiri juga mengalami kerancuan. Siapakah yang dimaksud publik? Jika rakyat, maka rakyat dari segmen yang mana, apakah politisi, budayawan, birokrat, atau akademisi? Masing-masing memiliki konsep berbeda dalam pendefinisian korupsi. Mereka,yang mampu menguasai dan mengendalikan opini masyarakat, adalah pihak yang dianggap memiliki legitimasi moral-politik dalam mendefinisikan korupsi.

Sementara itu, jika korupsi didefinisikan dengan menggunakan pendekatan hukum (legal approach), maka korupsi dapat diartikan sebagai pelanggaran terhadap aturan dan norma hukum yang berlaku. Kendati demikian, pendekatan hukum ini juga menuai banyak kritik. Pendekatan ini dinilai tidak tepat dan sangat rentan dengan praktek manipulasi serta intervensi kepentingan politik terhadap ranah hukum, sehingga membuat pasal-pasal aturan perundang-undangan menjadi semakin fleksibel dan berubah-ubah (William, 1987: 18; Sandhlotz \&Koetzle, 2000: 34). Meskipun perdebatan dalam 
upaya pencarian definisi korupsi ini tidak berkesudahan, tetapi definisi umum tentang korupsi acap kali muncul untuk merekonsiliasikan arus perdebatan yang terjadi,di mana definisi korupsi sejatinya sangat bergantung pada perasaan publik (public sense). Dasar idenya memang cenderung intuitif. Ketika korupsi secara sederhana dipahami sebagai penyalahgunaan kekuasaan atau jabatan publik untuk kepentingan pribadi, maka masyarakat akan memiliki intuisi tersendiri untuk membedakan apakah perilaku para pemangku jabatan itu cenderung merusak atau menguntungkan untuk mereka. Melalui pendekatan semacam itu, kemudian muncul konsep norma-norma universal yang diterima (the aceptable norms) di semua masyarakat, meskipun masing-masing sebenarnya memiliki definisi yang berbeda pula. Jadi, dapat disimpulkan bahwa korupsi merupakan perilaku menyimpang (deviant behaviour) yang dilakukan para pejabat publik yang melanggar norma-norma yang diterima secara umum (commonly aceptable norms) dan berlaku lazim, atau juga bisa dianggap sebagai aktivitas politik yang berbenturan dengan norma politik (Friederich, 1985: 15; Huntington, 1968: 59; Morris, 1991: 2).

Perdebatan dan pergulatan teoritik dalam upaya mencari definisi yang paling tepat dalam menjelaskan makna korupsi masih tak berujung, hingga sekarang. Bedirhanoglu (Bedirhanoglu,2007), dalam penelitiannya tentang kasus di Turki misalnya, mengkritik keras model pendefinisian korupsi ala neoliberalisme yang dinilai cenderung ahistoris, bias, dan kontradiktif. Bedirhanoglu menegaskan, cara pandang neoliberalisme terhadap penanganan anti-korupsi lebih cenderung ditekankan pada upaya memperkuat mekanisme pasar untuk menjamin lancarnya aliran modal, sementara pemahaman aspek kepentingan publik (public interest) lebih cenderung disesuaikan dengan kepentingan kelompok kapitalis transnasional,di mana setiap kelompok dan pihak-pihak yang tidak pro-pasar dan lebih cenderung menggunakan negara sebagai prosedur operasional kebijakan publik, baik di tingkat lokal maupun nasional, akan dilabeli sebagai

"korup" (Bedirhanoglu, 2007: 1251).

$$
\text { Sementara itu, Wayland }
$$

(Wayland,1998) di dalam proyek penelitiannya terhadap korupsi di bawah demokrasi di negara-negara Amerika Latin telah menemukan kesimpulan yang tidak jauh berbeda, bahwa reformasi atau agenda kebijakan pembaharuan yang dimotori oleh kelompok neoliberalis justru telah membuka berbagai celah dan kesempatan bagi menjamurnya praktek korupsi dan suap, khususnya mereka yang terlibat dalam penjualan perusahaan miliki negara (Seligson, 2002: 430). Penelitian serupa dilakukan oleh Sun dan Johnston (Sun \& Johnston,2009), yang menguji tentang peran demokrasi dan liberalisasi ekonomi dalam pemberantasan korupsi di India dan China. Sun dan Johnston (Sun \& Johnston, 2009) berpendapat bahwa, faktanya, demokratisasi dan liberalisasi pasar justru memunculkan fakta ironis yang justru mengabadikan praktek korupsi. Kesimpulan Sun dan Johnston itu tentu tidak spekulatif. Keduanya menemukan fakta bahwa liberalisasi pasar di negara berkembang justru semakin memperdalam disparitas sosial dan ekonomi masyarakat di negaranya. Pembuktian dari fenomena itu terjadi di sejumlah negara Afrika, Asia, dan Amerika Latin, di mana ide-ide Neoliberal telah ditransfer ke kawasan tersebut sebagai bagian dari program-program pembangunan negara-negara yang mengalami tekanan ekonomi dan finansial dalam jangka waktu yang panjang. Negara-negara tersebut mengalami perubahan dramatis dalam struktur politik dan ekonomi mereka dalam proses penyesuaian konsep neoliberalisme, seperti ketika kekuatan negara dilucuti dan dipangkas, sementara otoritas publik diserahkan pada superioritas pasar, dan skema perdagangan bebas dikuatkan oleh mengalirnya investasi asing yang semakin mapan. Perubahan dramatis itu merupakan hasil dari upaya untuk menstandarisasi negara dengan konsep pasar sebagaimana yang tertera dalam paket kebijakan ekonomi neoliberal. Namun dalam berbagai 
pengalaman, setelah beberapa dekade kebijakan itu dijalankan, kemiskinan justru tidak menunjukkan angka penurunan signifikan. Kemiskinan masih tetap menjadi persoalan yang tidak berkesudahan dan tidak terselesaikan sampai sekarang. Jika kondisi ini berlanjut dalam jangka panjang, maka situasi tersebut akan mengancam negaranegara menuju predikat baru sebagai negara yang gagal atau failed states (Manor, 1995; Kiely, 2007).

Situasi semacam itu menimbulkan ketegangan tersendiri dalam tatanan masyarakat dan pemerintahan hingga berpotensi melahirkan tirani baru pasca proses demokratisasi. Di sisi lain, kaum elite menikmati keistimewaan yang diperoleh dari praktek-praktek korupsi yang dijalankan secara kolektif dengan jaringan dan kelompoknya. Huntington (Huntington,1968:59-71) mengatakan bahwa ketika para elite politik cenderung meninggalkan fungsi profetik dalam kerjakerja politiknya, dan lebih mengutamakan akumulasi harta dan kekuasaan, maka individu-individu seperti itu akan cenderung melakukan penyalahgunaan kekuasaan dalam mencari akses ekonomi untuk kepentingan pribadi dan kelompoknya.
Sebaliknya, ketika potensi dan kekuatan ekonomi tidak menjadi perhatian utama dalam sikap dan perilaku elite politik, maka mereka akan cenderung menggunakan kekuatan ekonomi dan kekayaannya untuk mencari kekuasaan.

Dari penelusuran literatur di atas, sementara dapat disimpulkan bahwa proses pembaharuan atau reformasi yang berlandaskan pada prinsip neoliberal, sebagaimana yang terjadi di sejumlah negara berkembang baik di Afrika, Asia, dan Amerika Latin, terbukti tidak mampu menjamin efektivitas pemberantasan korupsi. Banyak dari negara-negara Afrika yang telah lama mengadopsi kebijakan reformasi neoliberal tidak mengalami peningkatan serius dalam upaya menekan tingkat korupsi. Hal itu dibuktikan oleh rendahnya tingkat indeks persepsi korupsi (corruption perception index) di mayoritas negara-negara di Afrika. Dalam berbagai kesimpulan, dikatakan bahwa konsep penguatan struktur pasar dan pengurangan otoritas negara di sektor publik negaranegara tersebut justru sering kali berakibat pada semakin melebarnya celah aturan dan kesempatan bagi perilaku korupsi.

Table 1.Indeks Persepsi Korupsi Negara-negara Sub Sahara Afrika (TI, 2013).

\begin{tabular}{|c|c|c|}
\hline RANK & COUNTRY/TERRITORY & SCORE \\
\hline 30 & Botswana & 64 \\
\hline 41 & Cape Verde & 58 \\
\hline 47 & Seychelles & 54 \\
\hline 49 & Rwanda & 53 \\
\hline 52 & Mauritius & 52 \\
\hline 55 & Lesotho & 49 \\
\hline 57 & Namibia & 48 \\
\hline 63 & Ghana & 46 \\
\hline 72 & $\begin{array}{l}\text { Sao Tome and } \\
\text { Principe }\end{array}$ & 42 \\
\hline 72 & South Africa & 42 \\
\hline 77 & Senegal & 41 \\
\hline 82 & Swaziland & 39 \\
\hline 83 & Burkina Faso & 38 \\
\hline
\end{tabular}

Menghadapi situasi patologis tersebut, teori modernisasi Weberian menawarkan konsep rasionalisasi otoritas, penguatan prosedur hukum, dan persamaan

\begin{tabular}{|r|lr}
\hline RANK & COUNTRY/TERRITORY & SCORE \\
\hline 127 & Madagascar & 28 \\
\hline 127 & Mali & 28 \\
\hline 136 & Cōte dlivoire & 27 \\
\hline 136 & Kenya & 27 \\
\hline 140 & Uganda & 26 \\
\hline 144 & Cameroon & 25 \\
\hline 144 & Central African & 25 \\
& Republic & \\
\hline 144 & Nigeria & 25 \\
\hline 150 & Guinea & 24 \\
\hline 153 & Angola & 23 \\
\hline 154 & Congo Republic & 22 \\
\hline 154 & Democratic Republic & 22 \\
& of the Congo & \\
\end{tabular}

\begin{tabular}{|l|ll}
\hline $\mathbf{1 5 7}$ & Burundi & 21 \\
\hline $\mathbf{1 5 7}$ & Zimbabwe & 21 \\
\hline $\mathbf{1 6 0}$ & Eritrea & 20 \\
\hline $\mathbf{1 6 3}$ & Chad & 19 \\
\hline $\mathbf{1 6 3}$ & Equatorial Guinea & 19 \\
\hline $\mathbf{1 6 3}$ & Guinea-Bissau & 19 \\
\hline $\mathbf{1 7 3}$ & South Sudan & 14 \\
\hline $\mathbf{1 7 5}$ & Somalia & $\mathbf{8}$ \\
\hline
\end{tabular}

The 2013 Corruption Peroeptions Index measures the perceived levels of public sector corruption in 177 countries/ territories around the world. To $s \theta \theta$ the full results go to:

www.transparency.org/cpi \#stopthecorrupt 
Konsep birokratisasi dalam ranah layanan publik dipercaya sangat ampuh menyapu praktek-praktek administrasi yang bercorak patrimonial. Kendati demikian, birokratisasi tetap juga tidak mampu menjamin meningkatnya pertanggungjawaban administrasi (administrative accountability). Kendala utama yang sering dihadapi oleh konsep birokratisasi adalah munculnya fragmentasi sektoral (sectoral fragmentation). Kondisi tersebut dapat melemahkan performa birokrasi, dan menghambat pola koordinasi antar-institusi atau lembaga satu dengan lembaga birokrasi yang lain. Fragmentasi sektoral ini juga mengakibatkan terjadinya ketumpangtindihan administratif (overlaps), kebijakan parsial, hingga konflik dan konfrontasi antar-lembaga negara, termasuk pula antar-lembaga anti-korupsi itu sendiri.

Pendekatan di atas kemudian ditentang oleh kelompok revisionis yang berusaha mengevaluasi peran penting dan kontribusi praktek korupsi dalam pembangunan politik dan ekonomi. Selama tahun 1960-an hingga 1980-an, beberapa akademisi dan ekonom internasional mempercayai bahwa praktek korupsi juga mendatangkan manfaat bagi pembangunan. Praktek korupsi dianggap mampu mendorong kelancaran proses transaksi ekonomi, tanpa harus menghadapi kendala berarti dalam birokrasi dan kebijakan publik. Karena itu, korupsi dipandang dapat menjadi stimulus yang efektif untuk mempercepat peningkatan bisnis dan investasi (Theobald, 1990; Bardhan, 1997). Korupsi juga diidentifikasi sebagai sebuah instrumen yang dapat menyeimbangkan stabilitas pasar dengan cara menyediakan lebih banyak kesempatan bagi para pelaku bisnis. Terlebih lagi, proses lobi, negosiasi dan korupsi juga dipercaya mampu memberikan kesempatan yang lebih intensif bagi para kelompok pengusaha untuk dapat meyakinkan pemerintah guna mendukung kebijakankebijakan pembangunan ekonomi (Myrdal, 1968), dan mengurangi efek negatif dari situasi ketidakpastian dalam dunia bisnis dan investasi (Leff, 1964). Ide-ide semacam itu telah didasarkan pada kalkulasi politik dan ekonomi jangka panjang di mana proses industrialisasi dapat dipertahankan oleh patronase politik-bisnis yang efisien dan inovatif (Leff, 1964). Sebab, dalam jangka panjang, keuntungan ekonomi dari dunia bisnis yang didukung oleh situasi korup itu dapat menutup biaya dan kerugian korupsi yang ditimbulkannya (Nye, 1989).

Terlepas dari perdebatan itu, perlu dipahami bahwa reformasi neoliberal bukanlah solusi yang otomatis untuk melawan korupsi. Negara-negara berkembang memiliki pengalaman yang bermacam-macam dengan program reformasi tersebut. Kesadaran publik akan bahaya tindakan korupsi seharusnya mendorong kemauan masyarakat untuk berbalik melawan korupsi dengan cara mengoptimalkan fungsi sistem demokrasi. Rose-Ackerman (Rose Ackerman, 1978: 216) menyatakan bahwa jika masyarakat benarbenar memahami fungsi demokrasi, maka mereka tidak akan mengikuti nasihat-nasihat para pakar ekonomi konvensional yang menyarankan untuk mengabaikan aspek moral dalam bersikap, serta lebih mengutamakan kepentingan ego-personal (self-seeking behaviour). Meskipun reformasi neoliberal dan upaya untuk membangun pemerintahan dan memberantas korupsi terus dijalankan secara intensif di negara-negara berkembang seperti Indonesia, tetapi instrumen demokrasi tetap kesulitan dalam mengatasi praktek korupsi. Kajian selanjutnya akan membahas tentang fungsi demokrasi dalam pemberantasan korupsi.

\section{Pseudo-Demokrasi dan Lemahnya Pemberantasan Korupsi}

Sejak terjadinya gelombang ketiga demokratisasi (the third wave of democratization) di dunia internasional pada tahun 1970-an dan gelombang liberalisasi ekonomi pada tahun 1980-an, negara-negara seperti Indonesia diharapkan mampu menekan angka korupsi, seraya memperbaiki sistem pemerintahan dan mempercepat agenda pembangunan. Upaya demokratisasi sering kali dilakukan dengan memromosikan agenda desentralisasi. Yakni 
upaya pemecahan kewenangan pemerintah pusat agar lebih dekat dengan masyarakat di akar rumput. Desentralisasi diperlukan untuk membentuk pemerintahan dari tingkat nasional ke daerah yang lebih demokratis. Itulah sebabnya donor internasional seperti IMF atau Bank Dunia telah menyarankan format politik desentralistik untuk menentang budaya politik terpusat dan korup. Dalam sistem terpusat, pemerintahan otoriter leluasa mengonsolidasikan kekuasaan rezim patrimonial mereka untuk mengontrol masyarakat dan memusatkan penguasaan sumberdaya yang dimiliki oleh negara ke tangan kaum elite semata.

Penguasa di dalam sistem otoriter juga lebih mudah memaksakan keputusan dan kebijakan mereka ke tingkat lokal hingga membuat pihak provinsi, kabupaten, kecamatan hingga desa kehilangan peran mereka dalam sistem pemerintahan itu sendiri. Pemerintahan yang terpusat adalah suatu sifat yang kondusif untuk korupsi dan kolusi (World Bank, 2000; Lal, 2000). Untuk itu, kehadiran desentralisasi diharapkan menjadi anti-tesis anti dari sistem sentralistik. Dengan memecah kekuatan dan kewenangan pemerintah pusat, desentralisasi diyakini dapat menjadi solusi dalam membangun tata pemerintahan lokal yang demokratis (Arghiros, 2001; Bardhan, 2002: 188). Secara konseptual, ketika demokrasi berjalan di tingkat lokal, pemerintahan yang lebih aspiratif dan bertanggung jawab terhadap aspirasi dan kebutuhan akar rumput akan lebih lebih mudah didirikan mengingat rakyat akan lebih mudah terlibat dalam proses perumusan kebijakan. Dengan demikian, tingkat korupsi dapat diminimalkan secara signifikan. Dalam struktur pemerintahan yang desentralistik, pemerintah akan dipaksa untuk lebih responsif terhadap warga mereka, dan juga sebaliknya, masyarakat diwajibkan untuk lebih aktif menuntut, mengarahkan, dan mewarnai proses kebijakan sehingga setiap keputusan yang diambil pemerintah benar-benar berasal dari masyarakat dan tidak tercabut dari akarnya. Jika sistem itu berjalan, maka agenda pembangunan kesejahteraan sebagai tujuan utama dari setiap pemerintahan menjadi semakin mudah, kian realistis, dan terukur.

Secara teori, demokrasi diyakini mampu menjadi instrumen ampuh dalam pemberantasan korupsi. Setidaknya terdapat dua prinsip yang melekat dalam sistem demokrasi, yaitu prinsip kesetaraan dan prinsip keterbukaan, yang notabene merupakan nilai-nilai fundamental dalam panggulangan korupsi. Sistem demokrasi memberikan mekanisme dan prosedur yang jelas kepada masyarakat untuk menuntut pertanggungjawaban (accountability) dan transparansi (transparency) dalam pemerintahan. Demokrasi juga mensyaratkan akuntabilitas, sistem peradilan independen, sistem check and balance dalam kekuasaan, kebebasan pers, dan penegakan hukum. Sederhananya, semakin tinggi kualitas demokrasi suatu negara, maka semakin efektif lembagalembaga negara itu dalam memberantas korupsi (Sandholtz dan Kotzle, 2000: 38; Blake dan Martin, 2006: 9). Penelitian yang dilakukan oleh Hellman (Hellman, 1998) di bekas negara-negara komunis juga menunjukkan hasil yang relatif sama, di mana semakin mapan prinsip-prinsip demokrasi itu terbangun, maka semakin rendah pula tingkat korupsi negara tersebut.

Kendati demikian, harus tetap digarisbawahi bahwa demokrasi tidak menjamin pemberantasan korupsi dapat berjalan secara efektif. Efektivitas lembagalembaga demokrasi dalam memberantas korupsi akan tergantung pada apa yang disebut oleh Sandholtz dan Kotzle (2000) sebagai 'norma-norma demokrasi'. Jika nilainilai demokrasi itu ada, maka demokrasi yang substantif akan semakin kuat untuk mendeligitimasi praktik korupsi dengan menyudutkannya sebagai perilaku yang tidak pantas (Ostrom, 1991; Oyugi 2000; Putzle, 1997). Penekanan substantif pada kelangsungan perilaku para aktor demokrasi dan seluruh elemen masyarakat yang ada memang sangat penting untuk dilakukan. Karena memang demokrasi hendaknya tidak dipahami dengan logika konstitusionalisme, di mana pembentukan lembaga-lembaga demokrasi lengkap dengan mekanismenya 
akan secara seolah otomatis membawa negara menjadi negara yang demokratis dan bebas korupsi. Nilai-nilai substantif demokrasi berupa akuntabilitas dan transparansi juga harus diperkuat dan ditumbuhkembangkan.

Bersikap akuntabel dan transparan merupakan ruh dari demokrasi yang mampu melahirkan tata kelola pemerintahan yang baik (good governance). Ketika masyarakat memiliki kesadaran dan pengetahuan politik yang cukup untuk memperkuat logika politik mereka agar lebih rasional, maka praktekpraktek korupsi akan menjadi lebih mudah untuk ditekan. Itu sebabnya, ketika strategi anti-korupsi telah dilaksanakan, namun belum didukung oleh watak masyarakat yang demokratis secara substansial, akan berpotensi muncul fenomena 'negara bayangan' (pseudo-state), yakni fenomena maraknya para penguasa yang memanfaatkan kekuasaan untuk mengontrol kekuatan pasar dan politik guna mencari imbalan dari praktek-praktek korup hingga membuat terjadi kebocoran besar dalam anggaran negara (Reno, 1995: 1; Harris Putih, 1999). Dalam studi desentralisasi, fenomena itu banyak terjadi di Sierra Leone, Afrika, Bolivia, Kolombia, Bengal Barat dan beberapa penduduk setempat di India, termasuk juga di beberapa provinsi di Indonesia (Crook \&Sverrisson , 2001: 37; Johnson, 2001: 525). Weyland (Weyland, 1998: 108-121) menyatakan bahwa di negaranegara Amerika Latin, praktek demokrasi justru telah memperluas kesempatan bagi terjadinya tindakan pidana korupsi dan penyuapan. Akibatnya, para politisi yang duduk seolah-olah merasa menjadi penguasa baru yang memiliki hak veto untuk mendukung atau menolak kebijakan publik yang sesuai dengan kepentingan pribadi dan golongannya. Kecenderungan semacam itu mendorong terbentuknya pemimpinpemimpin baru yang rentan terhadap praktek korupsi.

Sebagian pihak menilai bahwa pemberantasan korupsi tidak akan berjalan efektif jika tidak didorong oleh kemajuan ekonomi yang mapan. Sun dan Johnston (Sun \& Johnston,2009) menyatakan bahwa efektivitas gerakan anti-korupsi sangat bergantung pada pembangunan ekonomi, yang dapat menawarkan alternatif-alternatif tindakan ekonomi baru yang berguna untuk mengeliminasi korupsi. Sun dan Johnston menyarankan bahwa untuk mencapai tujuan anti-korupsi dan meningkatkan kualitas pemerintahan, negara harus membangun perekonomiannya terlebih dahulu, baru kemudian kualitas demokrasi akan mengikuti belakangan (Sun dan Johnston, 2009: 16). Sebagai bukti, para peneliti menggunakan studi kasus demokrasi di India yang telah berjalan lebih dari 50 tahun, tetapi terbukti tidak efektif dalam memberantas korupsi. Sebaliknya, sistem politik di China yang cenderung otoriter justru lebih agresif dalam menekan angka korupsinya dibanding India.

\begin{tabular}{llr}
\multicolumn{1}{c}{ Para peneliti } & meyakini & bahwa d \\
negara-negara & yang & kondis \\
perekonomiannya & lemah, & sistem
\end{tabular}
demokrasinya tidak akan bisa berjalan optimal dalam mendorong efektivitas strategi pemberantasan korupsi. Sebaliknya, perekonomian negara yang lemah itu justru akan mendorong terciptanya pola korupsi yang mudah menyebar hingga ke akar rumput, terfragmentasi dan sangat mengganggu stabilitas politik dan masa depan perekonomian bangsa (Sun \&Johnston, 2009: 13).

Fakta mencengangkan justru lahir dari belahan dunia lain, di mana langkahlangkah gerakan anti-korupsi yang paling berhasil justru berada di negara-negara yang perekonomiannya maju tetapi sistem politiknya kurang atau bahkan tidak demokratis. Contohnya adalah negaranegara di kawasan Asia Timur seperti Taiwan, Jepang, Korea Selatan yang kualitas demokrasi negara-negara tersebut banyak dipertanyakan. Kendati kurang demokratis, sistem pemerintahan mereka justru terbukti efektif dalam menekan tingkat korupsi yang dibuktikan oleh rendahnya angka indeks korupsi dibanding dengan negara-negara yang mengklaim demokratis seperti Indonesia, Thailand, India, dan Filipina. Sementara itu, negara-negara yang secara politik menjalankan praktek demokrasi, 
justru memiliki tingkat korupsi yang lebih tinggi. Satu hal yang perlu digarisbawahi bahwa demokrasi di negara yang tingkat perekonomiannya rendah akan cenderung rentan terhadap korupsi.

Tanpa keseimbangan antara pembangunan ekonomi dan pembangunan politik, korupsi akan semakin menggurita. Huntington (Huntington,1968: 59-71) mengatakan, keseimbangan antara pembangunan politik dan ekonomi merupakan salah satu faktor kunci dalam keberhasilan mencegah korupsi. Dia juga menggarisbawahi bahwa keberhasilan pengendalian korupsi bukan hanya ditentukan oleh sekadar ada dan tidaknya demokrasi dalam tata perpolitikan suatu negara, melainkan lebih ditentukan oleh proses interaksi antara elemen politik, aparat negara, masyarakat, pasar, dan lainnya. Demokrasi memang bisa menghalau korupsi jika dikelola dengan bertanggung jawab. Hal itu mensyaratkan adanya para elite yang amanah dan responsif terhadap aspirasi publik, akses politik yang terbuka bagi semua pihak, serta adanya kesamaan kesempatan bagi seluruh elemen sosial-politik untuk mewarnai proses pengambilan kebijakan publik.

Penciptaan suasana politik yang positif seperti itu harus didukung oleh sistem peradilan yang independen, kebebasan pers, transparansi sistem di seluruh sektor pemerintahan, serta kebebasan berserikat dan berpendapat. Ketika akses kesempatan di bidang politik dan ekonomi seimbang, maka korupsi dapat ditekan. Tetapi jika elit yang otonom dan akses menuju kekuasaan dan kesejahteraan tidak seimbang, maka korupsi akan merajalela. Sederhananya, jika terdapat situasi di mana para elite merasa terancam dan tidak aman karena merasa tidak mampu mengakses kekuasaan, ditambah dengan kondisi ekonomi yang terpuruk dan realitas institusi-institusi negara yang lemah sifatnya, maka demokrasi akan menjadi sangat rentan terhadap korupsi. Situasi semacam itu akan tergambar sangat jelas dalam negara-negara yang memiliki sistem pemerintahan patrimonial dan oligarkis.
Dalam sistem pemerintahan yang sifatnya patrimonial, elemen-elemen demokrasi akan berpotensi melakukan kolaborasi dengan kelompok-kelompok yang korup di dalam struktur pemerintahan. Idealnya, hubungan antara politisi dan kaum birokrat adalah sinergis guna mendukung proses pematangan demokrasi. Akan tetapi, kolusi dan kerjasama ilegal di antara keduanya justru sering kali mengacaukan keteraturan politik dan demokrasi itu sendiri. Para politisi bisa menekan para birokrat dengan otoritas politiknya, guna menyetujui praktek korupnya dengan menjanjikan pemberian perlindungan politik dan kesempatan-kesempatan promosi struktural. Sebaliknya, para birokrat juga bisa menjadi penentu nasib dan masa depan para politisi dalam jenjang karir politiknya dengan cara menjadi penyuplai kebutuhan finansial bagi para politisi tersebut.

Tidak hanya relasi antara politisi dan birokrat, hubungan antara politisi dan pengusaha dan para aktor bisnis lain juga berpotensi menciptakan jaringan koruptor dalam skala besar. Relasi antara politisi dan pengusaha memiliki pola yang relatif sama dengan hubungan politisi dan birokrat. Akibat dari lemahnya kemampuan finansial dan watak ketergantungan partai politik terhadap sumber-sumber dana eksternal, politisi sering kali menjadi sangat tergantung pada kaum pengusaha (Gomez, 2005; Aspinall dan Fealy, 2004; Erb, Sulistiyanto \&Faucher, 2005; Sakai, 2002). Situasi tersebut acap kali dimanfaatkan oleh para kelompok pengusaha untuk mencari patron atau figur-figur kunci yang akan menjadi jangkar bagi mereka untuk bermain dalam kompetisi dunia usaha yang lebih luas, terutama yang sangat berkaitan dengan wilayah kerja yang diatur atau dikelola oleh negara.

Patron-patron itu umumnya terdiri atas para tokoh utama yang menduduki posisi strategis dalam partai politik dan memiliki otoritas dalam mengendalikan wacana internal partainya guna mempengaruhi sikap politiknya di parlemen. Dengan adanya asas mutualisme atau prinsip resiprokal, relasi antara politisi dan 
pengusaha ini dapat menemukan langgamnya. Pembentukan jaringan patronase antara politisi dan pengusaha ini umumnya dibangun untuk mendapatkan perlindungan dan kesempatan-kesempatan strategis untuk melipatgandakan keuntungan bisnis para pengusaha, sementara para politisi mendapatkan keuntungan finansial dan fasilitas yang diperoleh dari pengusaha. Fatalnya, dalam konteks Indonesia, praktek korupsi dan kolusi semacam itu ternyata bukan monopoli para politisi dari partai politik pendukung pemerintah, tetapi juga banyak dilakukan oleh mereka yang berlatar belakang partai oposisi.

Akibatnya, ketika instrumen antikorupsi telah dimasuki oleh para predator semacam itu, maka agenda pemberantasan korupsi selanjutnya akan sarat dengan nuansa politisasi, manipulasi, dan intervensi. Sehingga spirit pemberantasan korupsi tidak lagi sama. Ironisnya, dalam sejumlah kasus, situasi patologis semacam itu justru disokong oleh para aktor dalam sistem demokrasi (Weyland, 1998: 108-21; Doig \&Theobald, 1999: 37-63). Kondisi semacam itulah yang tampaknya diidentifikasi oleh Liddle (Liddle,2007) sebagai salah satu bentuk 'pretended-democracy' atau demokrasi yang pura-pura, atau Aspinall (Aspinall,2005) menyebutnya sebagai quasi-democracy, sementara peneliti lain mengistilahkannya dengan predatoric democracy atau demokrasi yang dikendalikan oleh para politisi predator (Robinson, 2002; Hadiz, 2002), atau pseudodemocracy atau demokrasi semu (Haynes, 2001: 5), yang kesemuanya itu umumnya dipengaruhi oleh pelaksanaan demokrasi yang bercorak patrimonial, dangkal, tidak substantif.

\section{Intervensi, Manipulasi, dan Politisasi Lembaga Anti-Korupsi}

Demokrasi sebagai instrumen anti-korupsi telah membuahkan hasil yang sangat beragam. Minimnya praktek nilai-nilai demokrasi dalam perilaku politik para elite dan aparatur pemerintahan akan menjebak negara ke dalam praktek politik neopatrimonial. Vedi Hadiz (Hadiz, 2006) berpendapat bahwa dalam lingkungan demokrasi yang baru, praktek korupsi memang cenderung lebih sulit diberantas karena ia mengakar kuat di dalam jantung kekuasaan. Karena itu, Hadiz mengkritik keras teori neo-institutionalis yang menyatakan bahwa upaya-upaya reformasi neoliberal yang dicanangkan oleh sejumlah lembaga donor internasional di sejumlah negara miskin dan berkembang diyakini akan menghasilkan pola kerja dan tatanan pemerintahan baru yang teknokratis dan efektif untuk mencegah korupsi. Tetapi dalam prakteknya, menurut Hadiz, lembagalembaga demokrasi dan lembaga antikorupsi itu justru telah dibajak oleh kepentingan-kepentingan para politisi predator. Mereka terus berusaha untuk menciptakan penghalang berupa keruwetan birokratis dan politis untuk menghalangi mereka dari proses investigasi anti-korupsi. Usaha-usaha itu dilakukan dengan mengatasnamakan "agenda demokrasi" dan penciptaan tata kelola pemerintahan yang baik. Padahal sejatinya, mereka terus berusaha mengakali sistem dan regulasi yang notabene masih banyak kekurangan dan kelemahan. Para elite-elite predator itu telah menjebak demokrasi ke dalam kubangan lumpur perpolitikan yang tidak sehat, korup, dan kotor. Oleh karena itu, fase transisi politik menuju demokrasi menjadi sangat berkepanjangan, tidak jelas ujung pangkalnya, dan memaksa negara berada dalam jalur masa depan yang samar.

Dalam fase itu, elite politik bukan membawa proses demokrasi menuju upaya penguatan tata kelola pemerintahan yang baik, melainkan memanfaatkan otoritas dan sumber daya yang dimilikinya untuk mengamankan kepentingan pribadi dan loyalitas para penganutnya (Theobald, 1982; Crouch, 1979; Webber, 2006). Dalam kondisi semacam itu, masyarakat akan merasa kesulitan untuk membedakan antara aset dan properti milik elite pemimpinnya yang legal maupun yang ilegal secara hukum (Chaikin, 2001: 100). Sistem politik seolah tidak menghendaki adanya pembedaan antara kepala negara dan negara itu sendiri. Domain privat dan domain publik seolah 
menjadi wilayah yang menyatu dalam figur seorang pemimpin. Sementara, sistem dan regulasi yang ada juga telah diadaptasi dan dibentuk sedemikian rupa untuk melindungi aset dan kepentingan para pemimpin mereka. Pemimpin dapat menggunakan aturan untuk melegitimasi penjarahan ekonomi negara. Itulah metode "legalisasi korupsi” sebagaimana yang dilakukan oleh banyak pemimpin otoriter maupun mereka yang mengklaim diri sebagai pemimpin yang demokratis tetapi korup. Fenomena semacam ini dipandang dilihat oleh Chaikin (2001: 98) berpotensi memunculkan konsekuensi yang cukup fatal berupa lahirnya seorang 'diktator modern'.

Ketika perilaku elite semacam itu tidak mendapatkan perimbangan serius dari oposisi, baik dari intraparlementer maupun ekstraparlementer, instrumen negara akan terus dibajak untuk urusan kepentingan pribadi daripada kepentingan publik. Neopatrimonialisme semacam itulah yang menjadi landasan terbentuknya kultur korupsi dan klientelisme (clientelism) dan menyediakan kekebalan politik dan hukum pada para elite korup tersebut.

Data Bank Dunia (World Bank, 2009) menunjukkan bahwa kecenderungan pemberantasan korupsi di negara-negara berkembang saat ini memang meningkat signifikan. Namun, proses investigasi, penuntutan, dan penjatuhan hukuman kebanyakan hanya menyentuh koruptor kelas bawah. Kalangan elite yang korup (big fish) tetap tak tersentuh. The big fish atau koruptor kelas kakap adalah simbol dari kekuatan elite yang umumnya terdiri atas pejabat tinggi di politik, pemimpin pemerintahan, birokrasi maupun militer. Chaikin (Chaikin, 2001) memberikan contoh dari banyak kasus pemimpin besar politik dunia yang terbukti korup hingga mengacaukan agenda pembangunan nasional negara mereka masing-masing. Sebagai contoh di Iran, di mana Shah Iran yang telah melakukan korupsi sekitar US \$ 35 miliar selama 25 tahun pemerintahannya yang akhirnya ditumbangkan oleh kekuatan revolusi yang dikomandoi oleh Ayatollah Khomeini. Di Filipina, mantan Presiden
Ferdinand Marcos (1965-1986) juga telah terbukti menyalahgunakan uang negara dalam jumlah yang sangat mencengangkan hingga dicatat oleh Guinness Book of Recordssebagai "pencuri terbesar dalam sejarah". Di Haiti, mantan Presiden Papa Doc Duvalier (1951-1986) dan putranya terbukti mengorupsi antara US \$ 500 juta hingga US \$ 2 miliar, di mana selama 1960-1970, sekitar 877 persen dari pengeluaran pemerintah dinikmati oleh Duvalier dan pendukung politiknya (Chaikin, 2001: 99).

Untuk mengatasi hal itu, menurut Collier (Collier, 2000: 200), 'gebrakan besar' (the big push) sangat dibutuhkan untuk menghadirkan shock therapy dalam gerakan anti-korupsi dengan cara menargetkan aktor-aktor besar dan terkemuka yang korup (the big fish) dalam suatu negara. Collier berpendapat bahwa keberhasilan penuntutan dan penghukuman terhadap seseorang yang dipandang sebagai the big fish dapat menyebabkan perubahan dramatis yang memberanikan kaum reformis untuk lebih agresif dalam berperang melawan sistem yang korup. Meskipun kehadiran demokrasi muncul untuk memperkuat upaya-upaya tersebut, tetapi agenda pemberantasan korupsi sering kali diwarnai oleh pertimbangan politik. Gerakan antikorupsi tidak lagi menjadi upaya pencarian keadilan dan kebenaran, tetapi menjadi arena tarik ulur kepentingan yang setiap upaya investigasi, penuntutan, dan penetapan hukuman tidak kebal terhadap intervensi dan manipulasi politik dan kekuasaan.

Mengingat agenda pemberantasan korupsi menjadi ajang pertarungan kepentingan dan memiliki efek besar terhadap peta konfigurasi dan konstelasi perpolitikan nasional, maka seluruh elemen kekuasaan akan terus berusaha untuk mempengaruhi atau bahkan mengintervensi performa lembaga-lembaga anti-korupsi. Hasilnya, di sejumlah negara berkembang, lembaga-lembaga anti-korupsi cenderung berubah menjadi alat kepentingan dan kekuasaan. Tidak hanya di Indonesia, hal semacam ini juga terjadi di sejumlah negara Amerika Latin dan Afrika, di mana lembaga- 
lembaga pemberantasan korupsi telah berubah menjadi instrumen politik yang dipakai oleh para elite penguasa untuk mengamankan kepentingan mereka, "mendisiplinkan" aliansi politiknya, menjaga loyalitas pengikut, menjatuhkan rival, mengonsolidasikan kekuatan, serta mencegah setiap potensi ancaman dari pihak lawan dan kompetitor politik (Gillespie \&Okruhlik, 1991).

Karena itu, kelompok kepentingan yang berhasil memenangkan persaingan dalam lingkaran kekuasaan akan mampu menentukan arah kebijakan pemberantasan korupsi dan berpotensi merusak prinsipprinsip penegakan hukum dan keadilan sosial. Di negara-negara Afrika, baik yang otoriter maupun yang semi demokratis, ironi-ironi lembaga anti-korupsi semacam itu sering kali terjadi. Kekuasaan yang besar seorang pemimpin politik dapat leluasa mengintervensi arah pemberantasan korupsi, menentukan siapa yang akan menjadi target atau siapa yang tidak menjadi target dalam upaya pemberantasan korupsi (Tangri \&Mwenda, 2006; Bayart, 1993).Akibatnya, proses investigasi, penuntutan, hingga penjatuhan vonis yang seharusnya berada dalam koridor penegakan hukum kini berubah menjadi area politis. Dalam konteks Indonesia, fenomena politisasi lembaga anti-korupsi bukanlah hal baru. Proses peradilan telah menjadi area tarik ulur kepentingan para elite kekuasaan, sementara pemberantasan korupsi sendiri lebih sering diselesaikan dengan metode kompromi politik. Kepentingan penguasalah yang akan menentukan siapa yang akan menjadi target dan tidak menjadi target dalam agenda pemberantasan korupsi. Oleh karena itu, pemberantasan korupsi menjadi lahan yang sangat rentan terhadap manipulasi, intervensi, dan tekanan politik. Dampaknya adalah lembeknya lembagalembaga anti-korupsi ketika berhadapan dengan para elite kekuasaan. Tindakan semacam itu tentu merendahkan supremasi hukum dan mencederai rasa keadilan sosial di mata publik. Namun, dalam logika kekuasaan, sebuah kejahatan yang bisa dipertahankan dengan kekuatan politik akan menjadi kebenaran baru.

Untuk mengeliminasi semua kecenderungan itu, dibutuhkan hadirnya faktor kepemimpinan yang kuat. Mengaca pada keberhasilan Singapura di bawah Lee Kuan Yew atau Hongkong di bawah otoritas Inggris Raya, tampaklah bahwa komitmen moral dan kemauan politik pimpinan tertinggi menjadi faktor kunci dalam agenda pemberantasan korupsi. Pemimpin yang kuat akan menyediakan prinsip dasar keberhasilan kerja anti-korupsi, antara lain penyediaan sumber daya yang memadai, dorongan politik yang positif untuk menjaga independensi, dan memperkuat kekuatan lembaga anti-korupsi (Quah, 2003, 2009, Treisman, 2000). Komitmen moral-politik pemimpin tertinggi sebuah negara dibutuhkan sebagai perisai bagi munculnya serangan balik dari pihak-pihak yang berkepentingan untuk melemahkan agenda pemberantasan korupsi. Semakin efektif gerakan anti-korupsi, semakin kuat pula serangan balik yang berupaya melemahkannya. Jaringan kepentingan dari kelompok-kelompok tersebut bisa membajak instrumen kekuasaan negara, baik melalui lembaga legislatif, yudikatif, partai politik, perusahaan, maupun eksekutif sendiri, untuk mendegradasi kekuatan anti-korupsi.

Ketika elemen-elemen nondemokratis yang berseberangan dengan agenda pemberantasan korupsi tersebut mampu menguasai kekuatan politik dan birokrasi, gerakan anti-korupsi tak ubahnya hanya permainan politik belaka. Instrumen korupsinya akan cenderung enggan mengusut praktik korupsi kelas kakap yang dilakukan para elite dengan alasan demi menjaga stabilitas perpolitikan nasional. Hal tersebut dikarenakan tindakan tegas terhadap elite dianggap hanya akan menciptakan gonjang-ganjing politik yang mengacaukan pembangunan (Tangri dan Mwenda, 2006).

Saat ini fenomena itulah yang terjadi di Indonesia. Seluruh elemen kekuasaan telah jadi bagian integral dari mafia antipemberantasan korupsi. Hadirnya pemimpin kuat yang bisa jadi jangkar bagi efektivitas 
pemberantasan korupsi kian utopis. Presiden yang diharapkan mampu berdaya gebrak untuk menyelesaikan kasus-kasus besar korupsi justru lebih memilih bersikap tidak tegas (unassertive leadership style) dan cenderung cari selamat (face-saving strategy) karena kalkulasi kepentingan politik. Alasan klasik untuk tidak melakukan "intervensi hukum" melalui instrumen kekuasaan terhadap kasus-kasus besar yang membelit para elite justru akan semakin mempertegas betapa lemahnya kepemimpinan pemimpin kita saat ini.

Secara konseptual, intervensi tetap dibutuhkan untuk mempertahankan independensi dan efektivitas pemberantasan korupsi, terutama pada saat target-target besar (big fishes) itu menelikung substansi kebenaran dalam penegakan hukum. Sederhananya, anti-corruption without political will is nothing. Untuk itu, kepemimpinan politik yang kuat dalam sistem politik yang demokratis merupakan kebutuhan yang tidak dapat ditawar lagi untuk mengefektifkan agenda pemberantasan korupsi di tanah air. Untuk mengawal efektivitas kepemimpinan itu, dibutuhkan pengawalan yang ketat dari berbagai kekuatan masyarakat sipil. Civil society adalah satu-satunya pilar demokrasi yang masih sehat di negeri ini. Di kala wakil rakyat sebagai representasi politik publik tidak dapat dipercaya lagi, di saat lembagalembaga penegak hukum hanya berani bersikap keras terhadap wong cilik ketimbang kaum elite, maka kekuatan masyarakat sipil harus bersinergi dan bergerak menjadi kekuatan kontrol sosial yang efektif terhadap sistem yang terlanjur korup ini. Menyatunya gerakan kekuatan massa aksi yang mampu menentang penguasa korup dan menggoyahkan kekuatan jaringan mereka itulah yang sering kali diistilahkan dengan people power. Yakni sebuah tindakan transgresif dari sekelompok masyarakat untuk melakukan inovasi gerakan kolektif untuk memperjuangkan aspirasi masyarakat yang telah disepelekan oleh para penguasa.
Dalam bab ini, dijelaskan bagaimana reformasi neoliberal yang dipromosikan oleh para lembaga donor internasional dengan melakukan liberalisasi ekonomi, demokratisasi, pengurangan subsidi, dan minimalisasi fungsi pemerintah di ruang publik guna menguatkan mekanisme pasar, tidak serta-merta secara otomatis menjadi solusi yang efektif bagi pemberantasan korupsi. Sebaliknya, dalam banyak kasus, proses demokratisasi yang berjalan begitu cepat dan membuat sistem penegakan hukum tercerabut, justru menjebak negara dalam fase transisi politik yang berkepanjangan, dan membuat proses pematangan sistem hukum dan politik menjadi sulit dilakukan. Proses demokratisasi akan mampu menjadi instrumen yang efektif dalam pemberantasan korupsi, jika nilai-nilai substantif dari demokrasi itu dijalankan. Jika demokrasi hanya berjalan prosedural, maka agenda pemberantasan korupsi hanya akan menjadi ajang tarik ulur kepentingan dan sarat dengan kompromi politik di dalamnya.

Untuk itu, supremasi dan penegakan hukum (rule of law) harus memegang kendali utama dengan kekuatannya yang independen dan tidak memihak. Sementara itu, penegakan hukum harus ditopang oleh hadirnya pemimpin yang kuat dan memiliki komitmen yang besar terhadap agenda pemberantasan korupsi menjadi sangat penting adanya. Sebab, ketika negara didominasi oleh status quo, lembagalembaga demokratis dan lembaga pemberantasan korupsi sangat rentan terhadap tekanan intervensi dan manipulasi politik, maka kehadiran pemimpin yang mampu melindungi lembaga dan menjaga netralitas lembaga anti-korupsi, memperkuat sumber daya dan memberikan perlindungan penuh terhadap lembaga antikorupsi dari berbagai serangan kelompokkelompok kepentingan tertentu yang hendak melemahkan dan menjatuhkan kredibilitas, independensi, dan kapabilitas lembagalembaga anti-korupsi itu sendiri.

\section{Kesimpulan}




\section{Daftar Pustaka}

\section{Buku}

Aspinall, E.\&Fealy, G. eds. (2003) Local power and politics in Indonesia. Singapore and Canberra: Institute of Southeast Asian Studies and Research School of Pacific and Asian Studies, the Australian National University.

Bayart, J.F. (1993) The state in Africa: thepolitics of the belly. New York: Longman.

Bowser, D.(2001) Corruption trust, and the danger to democratisation in the former soviet union. Dalam: Lovell, D. ed.the Transition: essays on post communism. London: Ashgate Publishers.

Chaikin, D.A. (2001) Controlling corruption by heads of government and political elites. Dalam:Lamour, P.\&Wolanin, N.ed. Corruption and anti-corruption. Canberra: Asia Pacific Press; Australian Institute of Criminology.

Colongan, J.A. (2003) What is happening on the ground? The progress of decentralization.Dalam:Aspinall, E.\&Fealey, G.eds Local power and politics in Indonesia: decentralization and democratization. Singapore: Institute of Southeast Asian Studies.

Crook, R. C. \& Sverrison, A. S. (2001) Decentralisation and poverty alleviation in developing countries: acomparative analysis or, is West Bengal unique? Brighton: Institute of Development Studies at the University of Sussex.

Della Porta, D.(200o) Social capital, beliefs in government and political corruption. Dalam:Pharr, S.\& Putnam, R. eds. Disaffected democracies: what's trubling the trilateral countries?. Princeton: Princeton University Press.

Doig, A.\& Theobald, R. eds. (1999) Corruption and democratization, London: Frank Cass.

Erb, M. \& Sulistiyanto, P. ed. (2009) Deepening democracy in Indonesia; direct elections for local leaders (Pilkada). Singapore: ISEAS.
Erb, M., Sulistiyanto,P., \& Fucher. C. eds.(2005) Regionalism in postSuharto Indonesia. London and New York: Routledge Curzon.

Friederich, C.J. (1989) Corruption concepts in historical perspective. Dalam: Heidenheimer, A.J., Johnston, M., \& LeVine, V.T. eds. Political corruption: ahandbook. New Brunswick, NJ:Rasaction.

Fukuyama, F.(1998) Asian values and civilization.paper presented in the ICAS Fall Symposium "Asia's Challenges Ahead", University of Pennsylvania, 1998.

Gomez, E.T. ed.(2002) Political business in East Asia. London: Routhledge.

Gomez, E.T. (2005) The state, governance, and corruption in Malaysia. Dalam: Tarling, N.ed. Corruption and good governance in Asia. New York:Routledge.

Hadiz, V. (2006) Corruption and neo-liberal reform: markets and predatory power in Indonesia and Southeast Asia. Dalam: Robinson, R.ed. The Neo-liberal revolution; forging the market state. London: Palgrave Macmillan.

White, B.H. (1999) How India works: the character of the local economy. Cambridge: Commonwealth Lectures.

Heynes, J.ed. (2001) Democracy and political change in the third world. London and New York: Routledge/ECRP Studies in European Political Science.

Huntington, S. (1968) Political order in changing societies. New Haven, CT: Yale University Press.

Kitthananan, A. (2008) Developmental states and global neo-liberalism. Dalam: Kennett, P.ed.Governance, globalization and public policy. Cheltenham: Edward Elgar.

Klitgaard, R. (1998) Corruption: Beyond Shame, Apathy, Futility.paper presented at the book launch of Membasmi Korupsi, Jakarta, 17 September. Klitgaard, R, Controlling Corruption. California: University of California Press. 
.(1988) Controlling corruption. Berkeley: University of California Press.

Lal, D.(2000) The poverty of development economics. Delhi: Oxford University Press.

Leff, N.H. (1964) Economic developmenttrough bureaucratic corruption. Dalam: Heidenheimer, A.J., Johnson, M., \& LeVine, V.T. eds. Political corruption: ahandbook.

Leys, C.(1989) What is the Problem about Corruption?.Dalam:Heidenheimer, A.J., Johnson, M., \& LeVine, V.T. eds. Political corruption: ahandbook. New Bruncswick, NJ: Transaction.

Lipset, S.\&Lenz, B. (2000) Corruption, culture and markets. Dalam:Harrison, L. \& Huntington, S. eds. Culture matters. New York: Basic Books, pp. 112-24.

Manor, J. (1995) Politics and neoliberals.Dalam: Colclough, C. \& Manor, J.eds. State or market? Neo-liberalism and the development policy debate. Oxford: Clerendon Press, pp. 1-25.

Merton, R.K. (1957) Social theory and social structure. New York:Free Press.

Myrald, G. (1968) Asian drama: an enquiry into the poverty of nations. Vol. 2.New York: The Twentieth Century Fund.

Nye, J.S. (1989) Corruption and political development: acost-benefit analysis. Dalam: Heidenheimer, A.J., Johnson, M., \& LeVine, V.T. eds. Political corruption: a handbook. New Bruncswick, NJ: Transaction.

Ostrom, V.(1991) The meaning of American federalims: constituting a self governing society. San Francisco: Institute for Contemporary Studies Press.

Philp, M.(1997) Defining political corruption. Dalam: Heywood, P.ed. Political corruption. Oxford: Blackwell.

Putzle, J.(1997) Democratization in Southeast Asia. Dalam: Potter, D.et al. eds. Democratization. London: Polity Press.

Quah, J. (2003) Curbing corruption in Asia: acomparative study of six countries. Singapore: Eastern Universities Press.
Reno, W.(1995) Corruption and state politics in Sierra Leone. Cambridge: Cambridge University Press.

Robinson, R. (2002) What sort of democracy? predatory and neo-liberal agendas in Indonesia. Dalam: Kinnvall, C. \&Jonnson, K.eds. Globalization and democratization in Asia: the construction of identity. London: Routledge.

Robison, R.ed.(2005) Theneo-liberal revolution; forging the market state. London: Palgrave Macmillan.

Rogow, A.A., \& Lasswell, H.J, (1963) Power, corruption and rectitute. Englewood Cliffs. NJ: Prentice-Hall.

Rose-Ackerman, S.(1999) Corruption and government: causes, consequences and reform. New York: Cambridge University Press.

Sakai, M.(2002) Beyond Jakarta: regional authonomy and local societies in Indonesia. Adelaide: Crowford Publishing House.

Scott, J. C. (1972) Comparative politics corruption. Englewood Cliffts, NJ: Prentice-Hall.

Smith, T.M. (1993) Korupsi, tradisi dan perubahan di Indonesia. Dalam: Lubis, M.\&Scott, J.C. eds. Korupsi politik. Jakarta:Yayasan Obor Indonesia.

Stiglizt. (2002) Globalization and its discontent. New York: Public Affairs.

Theobald, R. (1990) Corruption, development and underdevelopment. Durham, NC: Duke University Press.

Williams, R .(1987) Political corruption in Africa. Aldershot, England:Gower.

World Bank. (2006) Justice for Poor Program. Local Government Corruption Study -WB Collaboration Capacity Building of Anti-Corruption NGO at Local Level, Idea Note. . (2000) Helping Countries Combat Corruption,: progress at the World Bank Since 1997, Operation Core Services and Poverty Reduction and Economic Management, Washington DC, 2000. . (2000) World Development Report 2000/1: attacking poverty. 
Oxford: Oxford University Press for World Bank.

\section{Artikel Jurnal}

Anderson, C. J. \& Tverdova, Y.V. (2003) Corruption, political allegiances, and attitudes toward government in contemporary democracies. American Journal of Political Science, 47 (1), pp. 91-109.

Aspinall, E. (2005) Elections and the normalization of politics in Indonesia. South East Asia Research, 13 (2), pp. 117-56.

Bardhan, P. (1997) Corruption and development: areview of isssues. Journal of Economic Literature $X X X V$, September, pp. 1320-46.

Bayley, D. (1967) The effect of corruption in a developing nation. Western Political Quarterly, 19 (4), pp. 719-32.

Blake, C. H. \& Martin, C. G. (2006) The dynamics of political corruption: reexamining the influence of democracy, Democratization, 13 (1), pp. 1-14

Chang, E. C. C. \& Chu, Y. (2006) Corruption and trust: exceptionalism in Asian democracies?, The Journal of Politics, 68 (2), pp. 259-271.

Collier, M. (2002) Explaining corruption: an institutional choice approach. Crime, Law and Social Change, 38 (1), pp. 132.

Collier, P. (2000) How to reduce corruption. African Development Review, 12 (2).

Crouch, H. (1979) Patrimonialism and Military Rule in Indonesia World Politics, 31 (4), pp. 571-587.

Hadiz, V. \& Robinson, R. (2005) Neo-liberal reforms and illiberal consolidations: the Indonesian paradox. Development Studies, 41 (2), pp. 220-241.

Hadiz, V. (2004) Decentralization and democracy in Indonesia; acritique of neo-institutioalist perspective. Development and change, 35 (4), pp. 697-718.

Hellman, J., (1998) Winnerstake all: the politics of partial reform in post- communist transitions. World Politics, 50, pp. 203-235.

Huntington, S. P. (1993) Theclash of civilizations.Foreign Affairs, 72 (3), pp. 22-49.

Kiely, R. (2007) Povertyreduction through liberalisation? neoliberalism and the myth of global convergence. Review of International Studies,33, pp. 415-434.

Lawson, L. (2009) The politics of anticorruption reform in Africa. Modern African Studies, 47 (1), pp. 73-100.

McCoy, J. \& Heckel, H. (2001) The emergence of a global anti-corruption norm. International Politics, 38, pp. 65-90.

Oyugi, O.W. (2000) Decentralization for good governance and development: the unending debate. Regional Development Dialogue, 21 (1).

Quah, J. (2009) Combating corruption in the Asia-Pacific countries: what do we know and what needs to be done? International Public Management Review, 10 (1), pp. 5-29.

Renoe, C. E. (2002) Institutionalized corruption: implications for legal reform in Indonesia and the need to make haste slowly. Stanford Journal of East Asian Affairs, 2.

Sandholtz, W.\& Koetzle, W. (2000) Accounting for corruption: economic structure, democracy, and trade. International Studies Quarterly, 44 (1), pp. 31-50.

Seligson, M. (2002) Theimpact of corruption on regime legitimacy: acomparative study of four latin american countries. Journal of Politics, 64 (2).

Sun, Y.\& Johnston, M. (2009) Doesdemocracy check corruption? Insights from China and India. Comparative Politics, 42 (1), pp. 1-19.

Tangri, \& Mwenda, A.M. (2006) Politics, donors and the ineffectiveness of anticorruption institutions in Uganda. Modern African Studies, 44 (1), pp. 101-124.

Theobald, R. (1982) Patrimonialism. World Politics, 34 (4), pp. 548-559. 
Treisman, D. (2000) The causes of corruption: A cross-national survey. Journal of Public Economics, 76(3), pp.399-457.

Villalon, R. (2007) Neoliberalism, corruption and legacies of contention: argentina's social movements 19932006. Latin American Perspectives, 34 (2), pp. 139-156.

Webber, D. (2006) Consolidated patrimonial democracy? democratization in post-Soeharto Indonesia. Democratization, 13 (3), pp. 396-420.

Weyland, K.(1998) The politics of corruption in Latin America. Journal of Democracy, 9, pp. 108-21.
Williams, R. (1999) New concepts for old?. Third World Quarterly, 20 (3).

\section{Artikel Online}

Hoffmann, B. \& Kaiser, K. (2002) The Making of the Big Bang and its aftermath: apolitical economy perspective [Online]. Tersedia dalam: <http://www1.worldbank.org/eap>

USAID (2006), Stock Taking on Indonesia's Recent Decentralization Reforms [Online]. Tersedia dalam: <http://pdf.usaid.gov/pdf_docs/PNAD H311.pdf $>$ 